\title{
Chemical composition and palaeobotanical origin of Miocene resins from Kerala-Konkan Coast, western India
}

\author{
Suryendu Dutta ${ }^{1, *}$, Monalisa Mallick ${ }^{1}$, Runcie Paul Mathews ${ }^{1}$, \\ Ulrich Mann $^{2}$, Paul F Greenwood ${ }^{3}$ and Rakesh Saxena ${ }^{4}$ \\ ${ }^{1}$ Department of Earth Sciences, Indian Institute of Technology Bombay, Mumbai 400 076, India. \\ ${ }^{2}$ Forschungzentrum Jülich, Institut für Chemie und Dynamik der Geosphäre, D-52425 Jülich, Germany. \\ ${ }^{3}$ John De Laeter Mass Spectrometry and WA Biogeochemistry Centre, The University of Western Australia, \\ 35 Stirling Highway, Crawley, WA 6009, Australia. \\ ${ }^{4}$ Birbal Sahni Institute of Palaeobotany, 53 University Road, Lucknow 226 007, India. \\ *e-mail:s.dutta@iitb.ac.in
}

The terpenoid composition of resins from the Miocene lignite horizons from the KeralaKonkan Coast, western India was analyzed by Curie-point pyrolysis-gas chromatographymass spectrometry (Cupy-GC-MS). The major pyrolysates were cadalene-based bicyclic sesquiterpenoids including some $\mathrm{C}_{30}-\mathrm{C}_{31}$ bicadinenes and bicadinanes typical of dammar resin from angiosperm plants of Dipterocarpaceae family. These plants are typically supported by tropical climates which the western Indian region was known to have experienced during early Tertiary period. The present study suggests that these palaeoclimatic conditions persisted until at least the Miocene epoch. These sesquiterpenoids which are commonly detected in many SE Asian crude oils may be utilised as useful biomarkers for petroleum exploration in the western Indian region.

\section{Introduction}

Fossilised resins have attracted considerable interest in the past few decades since the important contribution they can make to crude oils became known (see Stout 1995 and references therein). Resins are plant exudates or secretions which harden on atmospheric contact. Natural resins represent a complex organic mixture mostly contains terpenoids and/or phenolic compounds (Langenheim 1995). These biochemicals perform a range of key plant functions including protection from predators, antioxidants and ultraviolet light; provision of structural support (lignin) and pigmentation of flowers and other organs; as well as a signal mechanism to microbial and macro-fauna (Langenheim 1995, 2003).

The terpenoid composition of resins typically include a combination of mono-, sesqui-, di-, and triterpenoid fractions, although no resins are known to contain both di- and triterpenoid fractions (Langenheim 1995). Terpenoid composition varies with resin type which together with a structural resistance to diagenetic alteration underlines their value as sedimentary biomarker providing a direct link to their resin source. The characterisation of fossil resins can therefore provide important information about palaeovegetation and palaeoclimate. For example, our recent appraisal of the terpenoid composition of Eocene resins from Cambay and Kutch basins, western India (Dutta et al 2009; Mallick et al 2009) identified these resins as derived from Dipterocarpaceae which must have been supported by a warm, tropical climate during the Eocene epoch.

Here we report the chemical composition of Miocene resins from Kerala-Konkan Coast, western India, to track the affinity of the resin producing plants during aforementioned time and complementing our recent study of Eocene resins

Keywords. Fossil resin; Miocene; western India; sesquiterpenoids; geochemistry; geology; biogeosciences. 


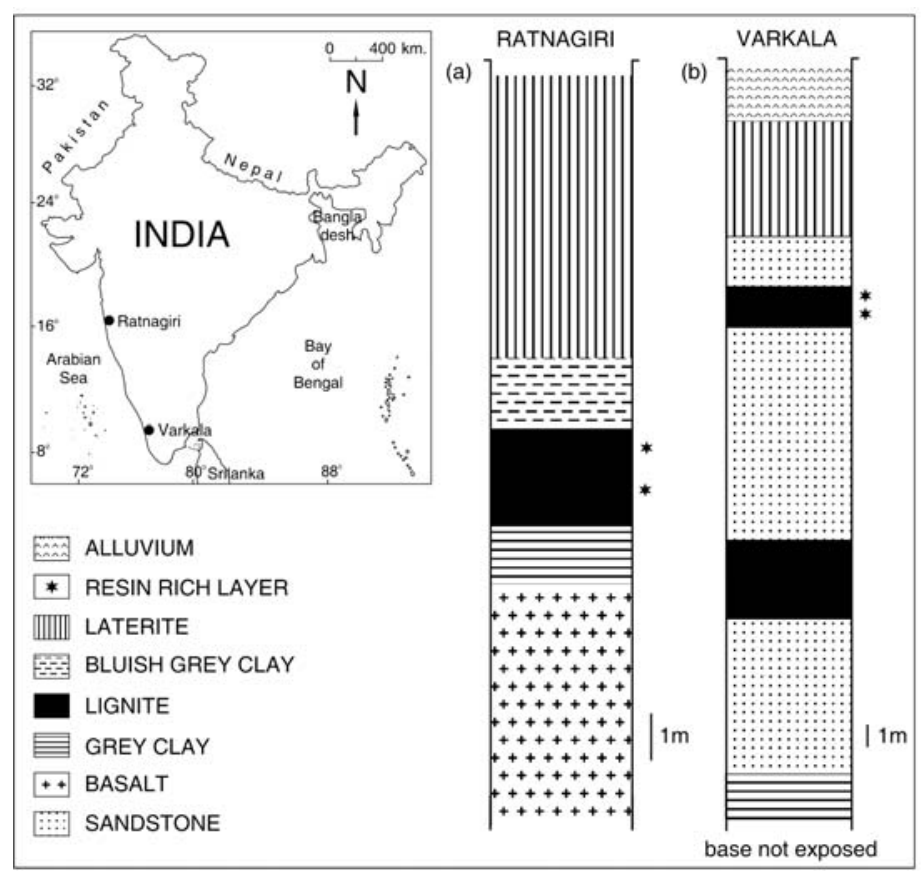

Figure 1. Location map of Ratnagiri and Varkala lignites with lithocolumns showing the positions of fossil resin rich layers.

from Cambay and Kutch basins of west India. This paper also discusses the contribution of fossil resins in hydrocarbon exploration.

\section{Samples and methods}

\subsection{Samples and geological background}

The resin samples were collected from Ratnagiri and Varkala, western India (figure 1). The resins from Ratnagiri were found for the first time in the lignite horizon from the lignitic beds exposed at Mirjole area, $4 \mathrm{~km}$ away from the city collector office $\left(16^{\circ} 59^{\prime} \mathrm{N}: 73^{\circ} 17^{\prime} \mathrm{E}\right)$ of Ratnagiri in the subsurface well section. Lignite is an integral part of the Sindhudurg Formation, with clay and carbonaceous matter as the other major lithologies and basalt the basement rock (figure 1a). The Ratnagiri lignite beds are of Miocene age (Kulkarni and Phadtare 1980) and were deposited under estuarine depositional condition (Phadtare and Kulkarni 1980). The resins from Varkala area were found in Warkallai group of rocks exposed at south Varkala cliff $\left(8^{\circ} 43^{\prime} \mathrm{N}: 76^{\circ} 42^{\prime} \mathrm{E}\right), 2.5 \mathrm{~km}$ west of Varkala railway station. The lumps of resins were present within lignite beds of Miocene age (Narayanan et al 2007). However, palynological assemblages suggest Eocene to Early Miocene age (Rao 1995). The lignites are interbedded with sandstone and clay layers. The studied resin samples were collected from the upper lignite seam (figure 1b). An extant resin from Dipterocarpaceae family (Genus Shorea) obtained from Purulia, West Bengal, eastern India was analyzed for comparative purposes.

\subsection{Curie-point pyrolysis-gas chromatography-mass spectrometry}

Resin samples were pyrolysed at $590^{\circ} \mathrm{C}$ for $10 \mathrm{~s}$ using a Curie-point pyrolyser (Pilodist) coupled directly to an HP 5890 Series II gas chromatograph (GC) coupled with a Finnigan MAT 95SQ mass spectrometer (MS). The GC was operated in the splitless mode and was equipped with a $50 \mathrm{~m}$ SGE BPX5 fused silica capillary column with an inner diameter of $0.22 \mathrm{~mm}$ and a film thickness of $0.25 \mu \mathrm{m}$. An initial oven temperature of $50^{\circ} \mathrm{C}$ was held for $2 \mathrm{~min}$, and then the oven was heated at a rate of $3^{\circ} \mathrm{C} / \mathrm{min}$ to $310^{\circ} \mathrm{C}$ maintained isothermally for a final $12 \mathrm{~min}$. The carrier gas was helium. The MS was operated in electron impact mode at an ionization energy of $70 \mathrm{eV}$ and a source temperature of $260^{\circ} \mathrm{C}$. Full scan mass spectra were recorded over a mass range of $50-1050 \mathrm{Da}$ at a total scan time of $1.0 \mathrm{~s}$. Peak assignments were based on correlation of GC retention time and mass spectral data to published literature and MS libraries.

\section{Results and discussion}

The total ion chromatograms (TICs) from Curie point Py-GC-MS of the fossil resins are 

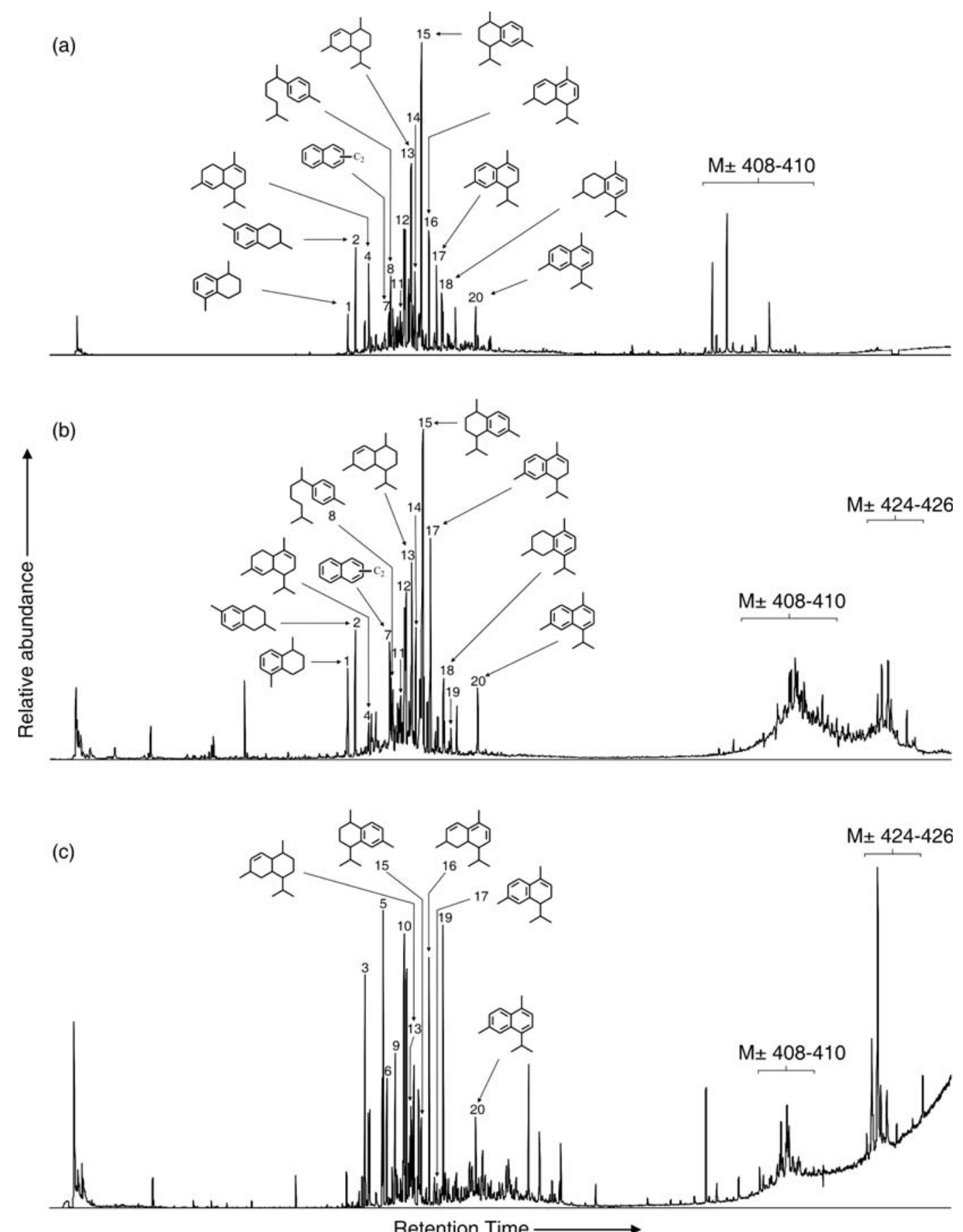

Figure 2. Total ion chromatograms resulting from Curie-point pyrolysis-GC-MS (pyrolysis at $590^{\circ} \mathrm{C}$ for $10 \mathrm{~s}$ ) of (a) Miocene fossil resin sample from Sindhudurg Formation, Konkan Coast, western India; (b) Miocene fossil resin sample from Warkallai Group, Kerala Coast, western India; (c) extant resin of genus Shorea (family Dipterocarpaceae) from Purulia, West Bengal, eastern India.

presented in figure $2(\mathrm{a}-\mathrm{b})$. The major products were $\mathrm{C}_{15}$ bicyclic sesquiterpenoids and their dimers (table 1). The sesquiterpenoids ranged in molecular weight from 198 to 206 Da reflecting up to five points of unsaturation. A consistently prominent isopropyl moiety $(\mathrm{m} / z 43)$ was indicative of a basic cadalene skeleton (van Aarsen et al 1991; Stout 1995). Calamanene (1,2,3,4-tetrahydrocadalene;
MW 202) was the most abundant product and 4-isoproply-1,6-dimethyl-1,2,3,4,4a,5,6,8aoctahydro-naphthalene (MW 206) the next most abundant product. Other products detected in relatively high abundance included 5,6,7,8tetrahydrocadalene (MW 202), $\propto$-calacorene (1-Isopropyl-4,7-dimethyl-1,2-dihydro-naphthalene; MW 200), cadalene (MW 198) $\propto$-muurolene 


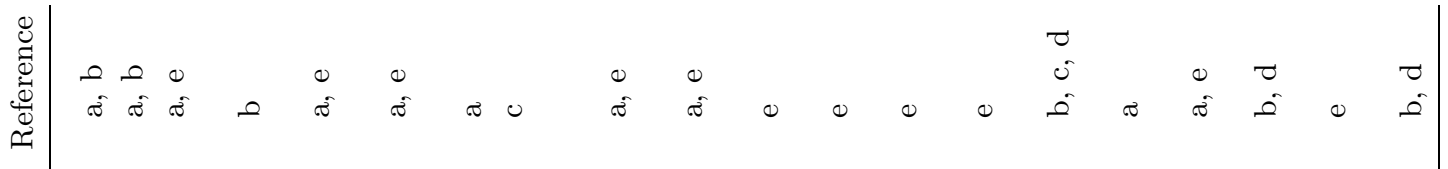

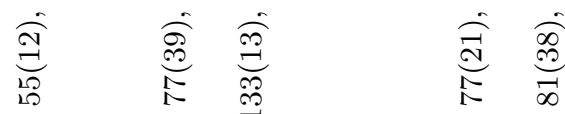

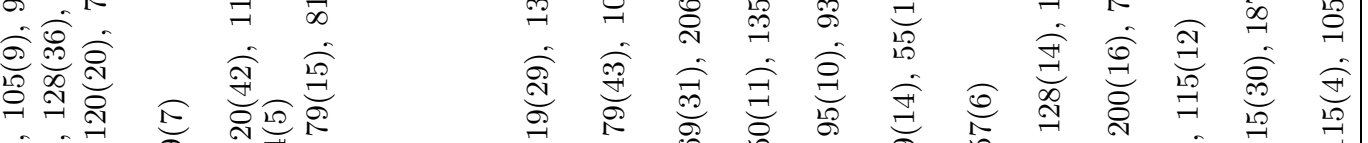

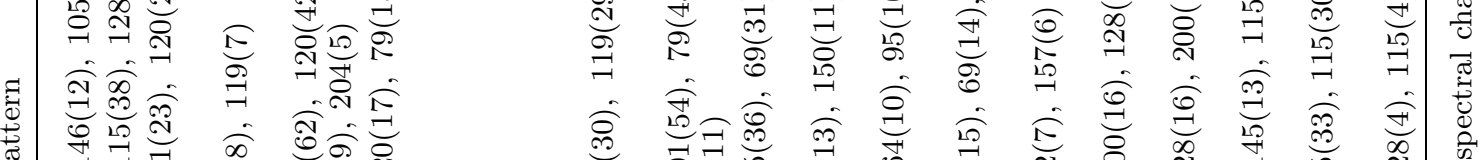

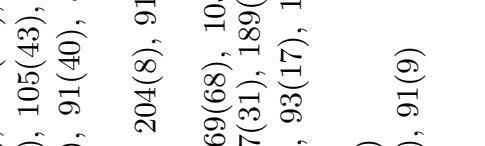

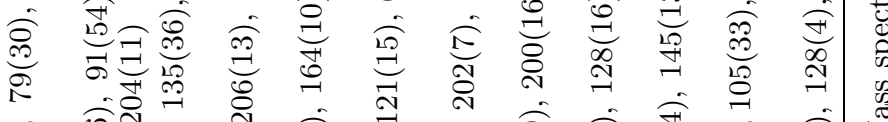

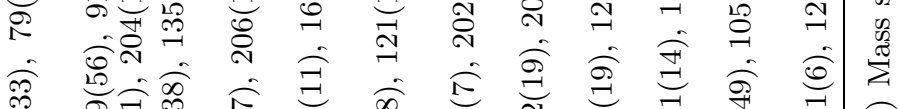
政

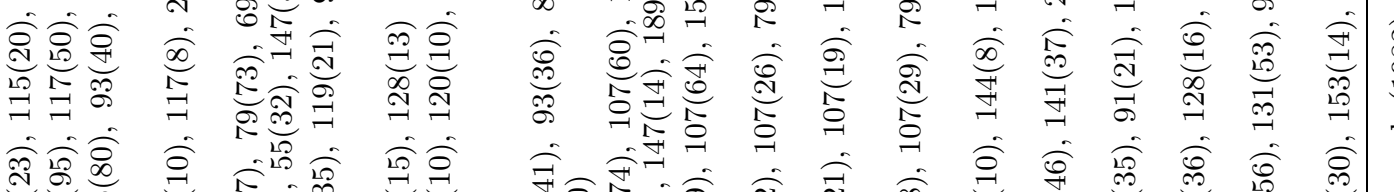

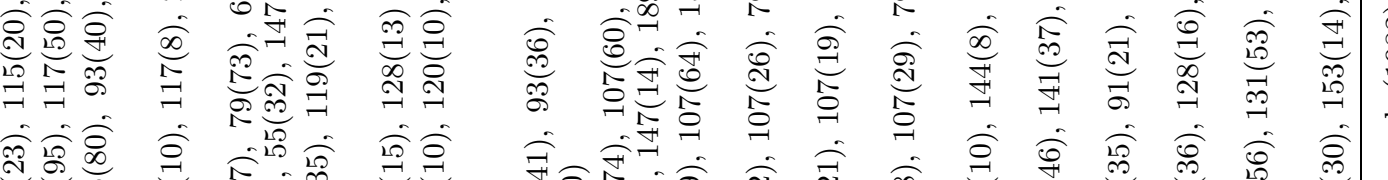

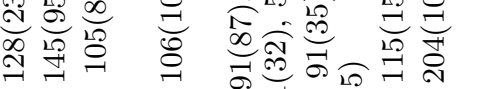

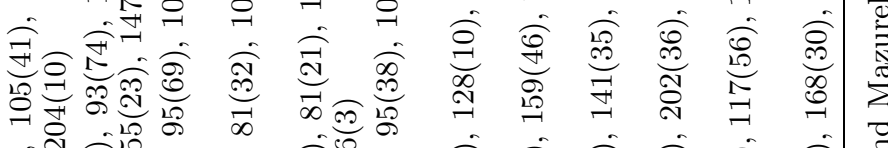

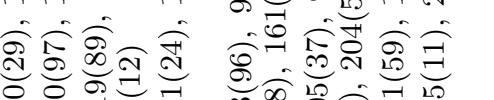

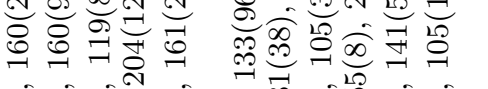

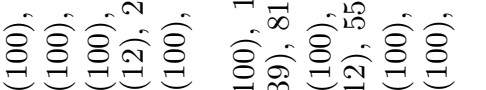

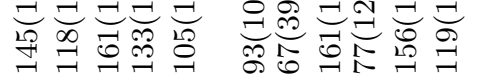

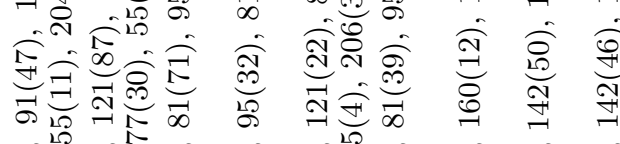

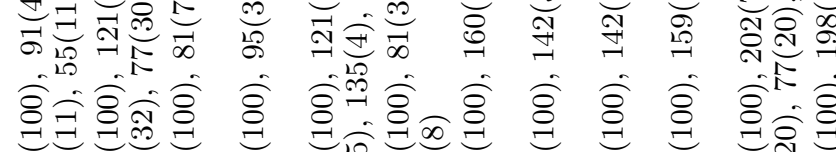

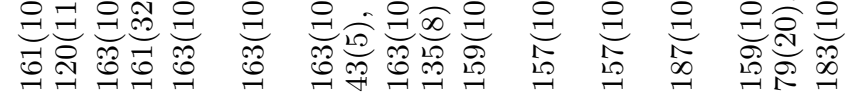

\section{\&}

뵤요

\section{8}

\&

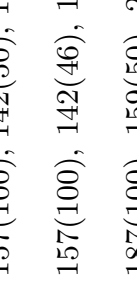


(1-Isopropyl-4,7-dimethyl-1,2,4a,5,6,8a-hexahydronaphthalene; MW 204) and dihydrocurcumene (1-(1,5-dimethyl-hexyl)-4-methyl-benzene; MW 204). Several polymethylnaphthalenes (e.g., 1,5-dimethyl-1,2,3,4-tetrahydro-naphthalene and 2,6-dimethyl-1,2,3,4-tetrahydro-naphthalene) were also abundantly found in the pyrolysis products of resins.

A separate distribution of peaks at higher retention times mostly comprised $\mathrm{C}_{30} \mathrm{H}_{48}$ dimers (MW 408-410) attributed to $\mathrm{C}_{30}$ bicadinenes on the basis of their strong $m / z$ 201-205, $\mathrm{m} / z$ 159-163 and $m / z 365-367$. These are diagnostic biomarkers of dammar resins derived from angiosperm family Dipterocarpaceae (Anderson et al 1992; Stout 1995). Several $\mathrm{C}_{31}$ bicadinanes and bicadinenes (MW 424-426; Pearson and Alam 1993) were additionally detected in the pyrolysates of the resin from Varkala.

The corresponding pyrolysis data from the extant resin also comprised a dominant distribution of $\mathrm{C}_{15}$ bicyclic sesquiterpenoids (figure 2c) and lesser amounts of $\mathrm{C}_{30}$ bicadinenes (MW 408-410) along with several $\mathrm{C}_{31}$ bicadinanes and bicadinenes (MW 424-426). The extant resin also showed some of the same terpenoid speciation as the fossil resin. For example, calamanene (1,2,3, 4-tetrahydrocadalene), 4-Isoproply-1, 6-dimethyl-1, 2,3,4,4a,5,6,8a-octahydro-naphthalene (MW 206), 5,6,7,8-tetrahydrocadalene (MW 202), $\propto$-calacorene (1-Isopropyl-4,7-dimethyl-1,2-dihydro-naphthalene; MW 200), cadalene (MW 198) were detected in high abundance from all studied samples. Their preservation in the fossil resin reflects minimal diagenetic alteration of these terpenoid biomarkers.

Previous research has distinguished three structurally distinct polymeric fossil resins based on labdanoid (diterpenoid), cadinane (sesquiterpenoid) and styrene polymeric units which derive from different plant sources. Both coniferales and Leguminosae, a family of angiosperm can yield polyditerpenoid resins (Anderson et al 1992). Cadinane based resins only derive from Dipterocarpaceae and Mastixioideae of the Cornaceae family of angiosperms (Anderson et al 1992; van Aarssen et al 1990, 1994). Polystyrene resins have been solely attributed to Hammelidaceae (Genus Liquidambar) angiosperms (see Anderson et al 1992).

The occurrence of $\mathrm{C}_{15}$ bicyclic sesquiterpenoids with cadalene carbon skeleton and their dimers (bicadinanes) in the present fossil resins identify these as a Dipterocarpaceae-sourced dammar resins. This is consistent with the previous attribution of a fossil wood from the lignite beds of Sindhudurg formation (Ratnagiri) to the Shoreoxylon vayganiensis sp. nov. of the
Dipterocarpaceae family (Srivastava and Saxena 1998). Dipterocarpaceae angiosperms grow abundantly in warm and humid climate, hence are often prolific in tropical rain forests (Langenheim 1995). Palynological records do suggest that a warm humid climate prevailed in the Kerala-Konkan coast during the Miocene (Phadtare and Kulkarni 1980; Rao 1995). Dipterocarpaceae were abundant on the Indian subcontinent during Neogene times (Lakhanpal 1970) and our recent biomarker studies of Eocene resins from Cambay and Kutch basins, western India suggest that this angiosperm family may be detected in Indian sediments date back to the Early Eocene (Dutta et al 2009; Mallick et al 2009). Fossil record also confirms that Dipterocarpaceae evolved in India since Palaeogene (Prasad et al 2009).

Bicadinanes have been detected in many SE Asian crude oils including Qiongdongnan (South China; van Aarssen et al 1992a), Surma (Bangladesh; Alam and Pearson 1990, 1992; Pearson and Alam 1993), Central Myanmar (Mayanmar; Curiale et al 1994), South Sumatra, West Irian Jaya, Ardjuna, Lumpas, Mahakam Delta (Indonesia; van Aarssen et al 1990; Murray et al 1994; Sosrowidjojo et al 1994; Stout 1995) and Lower Assam (India; Pande et al 1994) basins. This prevalence suggests $\mathrm{C}_{15}$ bicyclic sesquiterpenoids and their dimers will be useful biomarkers for source rock-oil and oil-oil correlations vital to petroleum explorations in this region. The $\mathrm{C}_{15}$ bicyclic sesquiterpenoid, especially cadalene and their dimers (bicadinanes) can also reflect thermal maturity of source rocks which has been proved to be useful for oil exploration purposes (Peters et al 2005 and references therein). Significantly, polycadinene biomarkers can survive thermal decomposition up to $\sim 80^{\circ} \mathrm{C}$ (Tegelaar and Noble 1994) and escape microbial and chemical alteration during early diagenesis.

\section{Conclusions}

The pyrolysis products of Miocene resins from Karala-Konkan Coast, western India contain cadalene-based aromatic, saturated, and unsaturated $\mathrm{C}_{15}$ bicyclic sesquiterpenoids and their dienes, $\mathrm{C}_{30}-\mathrm{C}_{31}$ bicadinanes and bicadinenes. These are diagnostic biomarkers of dammar resins which are derived from angiosperm family of Dipterocarpaceae. The presence of these terpenoids in both fresh and fossilized resins clearly suggests that dammar resins undergo minimal chemical changes during fossilizations. Our ongoing investigations suggest that detailed studies of these terpenoid biomarkers from Tertiary sediments and oils from western India would be beneficial and 
appropriate for understanding the contribution of dammar resins to the generation of hydrocarbon in this region.

\section{Acknowledgements}

The authors are thankful to IIT Bombay, India for providing infrastructure and financial support. Council for Scientific and Industrial Research (CSIR), India is acknowledged for providing financial support to M Mallick and R P Mathews. We thank U Disko for extending support during sample analysis.

\section{References}

Alam M and Pearson M J 1990 Bicadinanes in oils from the Surma Basin, Bangladesh; Org. Geochem. 15 461-464.

Anderson K B, Winans R E and Botto R E 1992 The nature and fate of natural resins in the geosphere-II. Identification, classification and nomenclature of resinites; Org. Geochem. 18 829-841.

Chaler R and Grimalt J O 2005 Finger printing of Cretaceous higher plant resins by infrared spectroscopy and gas chromatography coupled to mass spectrometry; Phytochem. Anal. 16 446-450.

Curiale J A, Kyi P, Collins I D, Din A, Nyein K, Nyunt M and Stuart C J 1994 The central Myanmar (Burma) oil family - composition and implications for source; Org. Geochem. 22 237-255.

Czechowski F, Simoneit B R T, Sachanbiński M, Chojcan J and Wołowiec S 1996 Physicochemical structural characterization of ambers from deposits in Poland; Appl. Geochem. 11 811-834.

Dutta S, Mallick M, Bertram N, Greenwood P F and Mathews R P 2009 Terpenoid composition and class of Tertiary resins from India; Int. J. Coal Geol. 80 44-50.

Kulkarni A R and Phadtare N R 1980 Leaf epidermis of Nypa from lignitic beds of Ratnagiri district, Maharashtra; Geophytology 10 125-128.

Lakhanpal R N 1970 Tertiary floras of India and their bearing on the historical geology of the region; Taxon 19 675-694.

Langenheim J H 1995 Biology of amber-producing trees: Focus on case studies of Hymenaea and Agathis; In: Amber, Resinite, and Fossil Resins (eds) K B Anderson and J C Crelling; ACS Symposium Series 617 $1-31$.

Langenheim J H 2003 Plant Resins - Chemistry, Evolution, Ecology and Ethnobotany. (Portland: Timber Press) $586 \mathrm{pp}$.

Mallick M, Dutta S, Greenwood P F and Bertram N 2009 Pyrolytic and spectroscopic studies of Eocene resin from Vastan Lignite Mine, Cambay Basin, western India; Geol. Soc. India 74 16-22.

Murray A P, Summons R E, Boreham C J and Lesley M D 1994 Biomarker and $n$-alkane isotope profiles for Tertiary oils: Relationship to source rock depositional setting; Org. Geochem. 22 521-542.
Narayanan V, Anirudhan S and Grottoli A G 2007 Oxygen and carbon isotope analysis of the Miocene limestone of Kerala and its implications to palaeoclimate and its depositional setting; Curr. Sci. 93 1155-1159.

Pande A, Uniyal A K and Chandra K 1994 Genetic correlation of biodegraded crude oils from Lower Assam, India using biomarker compositions; Org. Geochem. 21 971-977.

Pearson M J and Alam M 1993 Bicadinanes and other terrestrial terpenoids in immature Oligocene sedimentary rocks and a related oil from the Surma Basin, NE Bangladesh; Org. Geochem. 20 539-554.

Peters K E, Walters C C and Moldowan J M 2005 The Biomarker Guide: Biomarkers and Isotopes in Petroleum Systems and Earth History (Cambridge: Cambridge University Press) $619 \mathrm{pp}$.

Phadtare N R and Kulkarni A R 1980 Palynological investigation of Ratnagiri lignite, Maharashtra; Geophytology 10 158-170.

Prasad V, Farooqui A, Tripathi S K M and Garg R 2009 The evidence of Late Palaeocene-Early Eocene equatorial rain forest refugia in south-western Ghats, India; J. Biosci. 34 1-21.

Rao M R 1995 Palynostratigraphic zonation and correlation of the Eocene-Early Miocene sequence in Alleppey district, Kerala, India; Rev. Palaeobot. Palynol. 86 325-348.

Simoneit B R T and Mazurek M A 1982 Organic matter of the troposphere - II. Natural background of biogenic lipid matter in aerosols over the rural western United States; Atmos. Environ. 41 S4-S24.

Sosrowidjojo I B, Alexander R and Kagi R I 1994 The biomarker composition of some crude oils from Sumatra: Org. Geochem. 21 303-312.

Stout S A 1995 Resin-derived hydrocarbons in fresh and fossil Dammar resins and Miocene rocks and oils in the Mahakam Delta, Indonesia; In: Amber, Resinite, and Fossil Resins (eds) K B Anderson and J C Crelling; ACS Symposium Series 617 43-75.

Tegelaar E W and Noble R A 1994 Kinetics of hydrocarbon generation as a function of the molecular structure of kerogen as revealed by pyrolysis-gas chromatography; Org. Geochem. 22 543-557.

van Aarssen B G K, Cox H C, Hoogendoorn P and de Leeuw J W 1990 A cadinene biopolymer in fossil and extant dammar resins as a source for cadinanes and bicadinanes in crude oils from Southeast Asia; Geochim. Cosmochim. Acta 54 3021-3031.

van Aarssen B G K, de Leeuw J W and Horsfield B 1991 A comparative study of three different pyrolysis methods used to characterise a biopolymer isolated from fossil and extant dammar resins; J. Anal. Appl. Pyrolysis 20 $125-139$

van Aarssen B G K, Quanxing Z and de Leeuw J W 1992a An unusual distribution of bicadinanes, tricadinanes and oligocadinanes in sediments from the Yacheng gasfleld, China; Org. Geochem. 18 805-812.

van Aarssen B G K, Hessels J K C, Abbink O K and de Leeuw JW 1992b The occurrence of polycyclic sesqui-, tri-, and oligoterpenoids derived from a resinous polymeric cadinene in crude oils from Southeast Asia; Geochim. Cosmochim. Acta 56 1231-1246.

van Aarssen B G K, de Leeuw J W, Collinson M, Boon J J and Goth K 1994 Occurrence of polycadinene in fossil and recent resins; Geochim. Cosmochim. Acta $\mathbf{5 8}$ 223-229. 